\title{
AN IMPROVED DYNAMIC SOLAR COLLECTOR MODEL INCLUDING CONDENSATION AND ASYMMETRIC INCIDENCE ANGLE MODIFIERS.
}

\author{
B. Perers \\ Department of Civil Engineering, Technical University of Denmark, Brovej, Building 118, DK-2800 Kgs. \\ Lyngby, Denmark; Phone: +45 452519 53. E-mail: beper@byg.dtu.dk.
}

\begin{abstract}
For simulation of solar + heat pump systems a dynamic collector model is needed that can handle operation below the dew point of the ambient air (condensation). For some collectors also complex incidence angle behaviour for beam radiation and more complicated acceptance of diffuse radiation has to be handled. The dynamic collector model from the EN12975 collector test standard is used as basis. The TRNSYS 16 simulation model is written so that collector parameters derived from an EN12975 test, can be used directly without conversion. In case of collectors that face condensation energy flows an additional parameter/term is introduced to the collector model and test procedure in EN12975. The paper will describe the model and also proposals for adjustment of the test procedure to derive the new parameters from a standard test. Most of the individual parts of this work has been developed and published during a 33 year period based on international cooperation within the IEA SH\&C programme in Task III, VI, VIII, 14, 26 and 32.
\end{abstract}

\section{Introduction}

Dynamic solar collector modelling under real weather conditions is complicated. There are many second and third order effects present in the collector energy balance. To the authors experience it is most important to have the optical modelling as close to reality as possible.
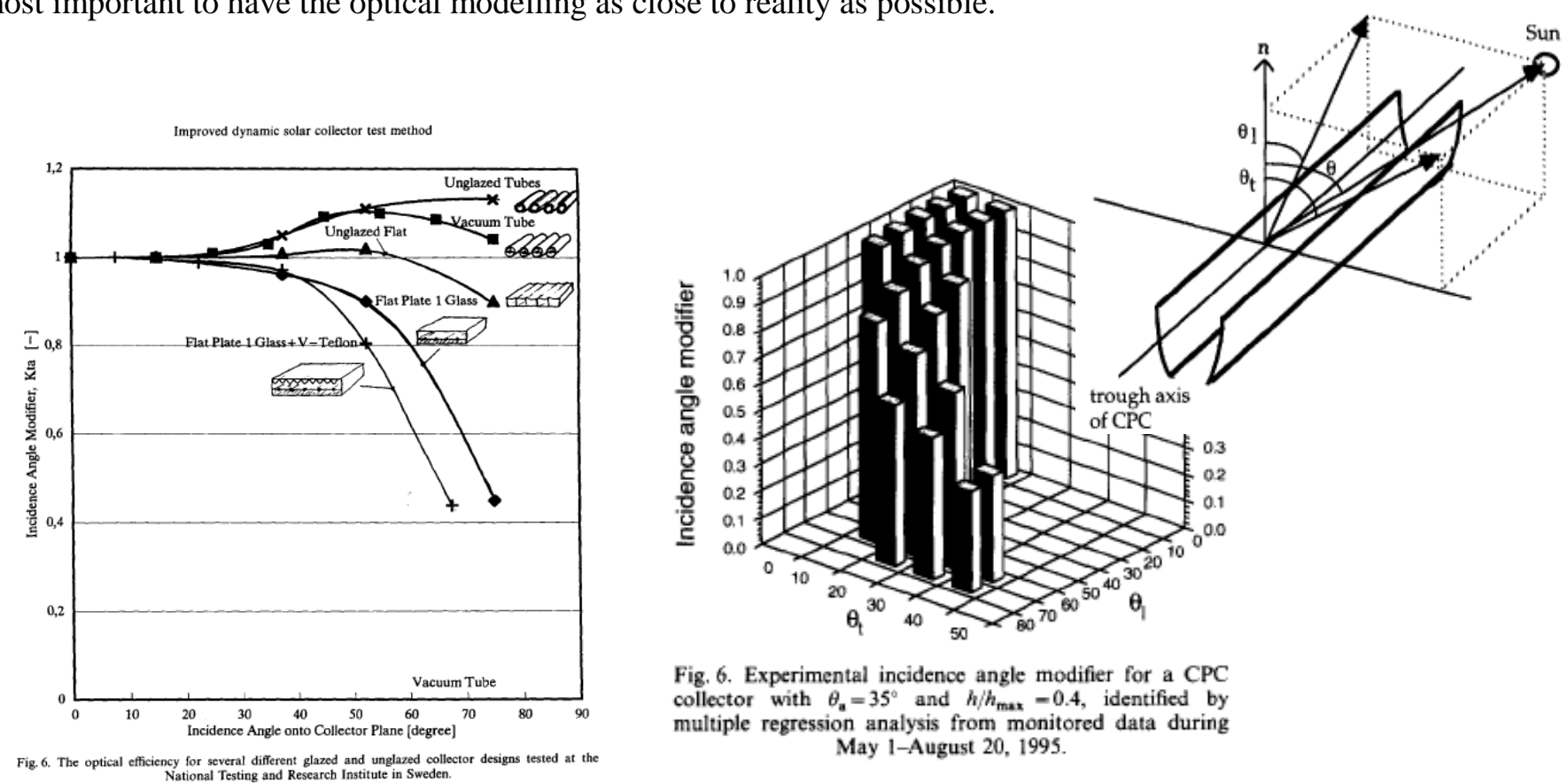

Fig. 6. Experimental incidence angle modifier for a CPC collector with $\theta_{\mathrm{a}}=35^{\circ}$ and $h / h_{\max }=0.4$, identified by multiple regression analysis from monitored data during May 1-August 20, 1995 .

Figure 1. Examples of measurement and modelling of incidence angle effects [2] and [3]. The right diagram shows the possibility to determine a $3 \mathrm{D}$ surface for $\mathrm{K}_{\theta b}\left(\theta_{\mathrm{L}}, \theta_{\mathrm{T}}\right)$ from dynamic testing. 
For system simulation, collector testing and accurate calculation of annual kWh output, a simplified but still accurate enough collector model is needed. The compromise between accuracy and complexity is the main achievement of this work obtained during a 33 year research period. The collector modelling without condensation used in EN12975 is described in [1], [2], [4] and [24].

When using solar collectors in heat pump systems, low operating temperatures, may occur and add to the performance, due to condensation on the absorber surface. Work on this, is presented in $[8,9,10]$

Figure 2 show a test of one collector designs for heat pump systems. The diagram to the right in fig 2 show the annual energy flows at low operating temperatures between 0 and 20 degree $\mathrm{C}$.

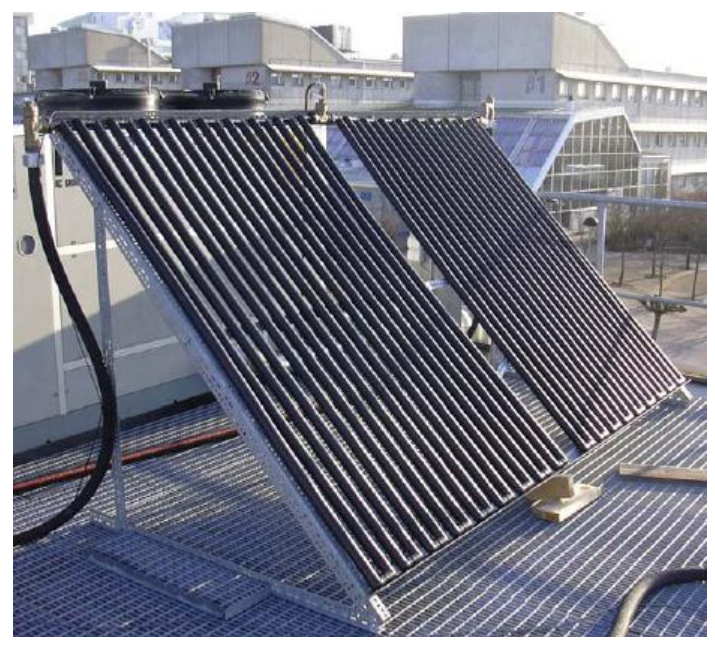

Unglased Solar Absorber Energy Flows

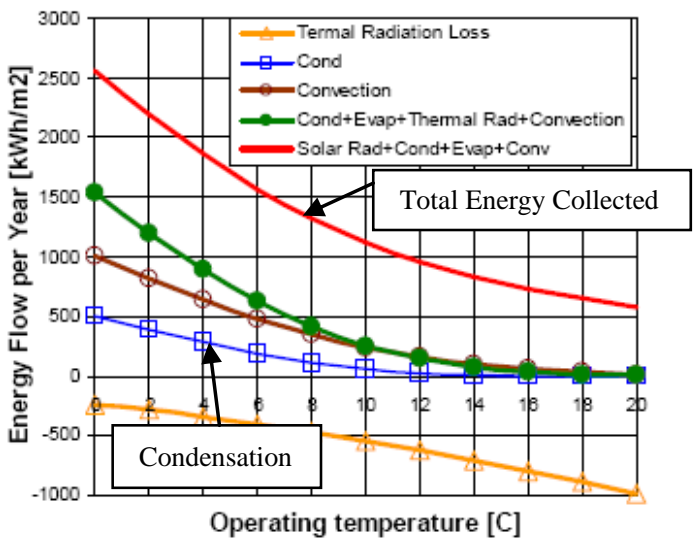

Figure 2. Example of an unglazed collector that can operate below the dew point and extract energy also from condensation. The unglazed collector model from EN12975 is used, only with the addition of a condensation term. Reference [11] and [12].

Also other extreme collector designs as concentrating collectors can be handled with the same model and test method. Figure 3 shows test results that compare calculated and measured thermal performance for a two axis tracking collector. Orange is measured and the blue curve is model results.
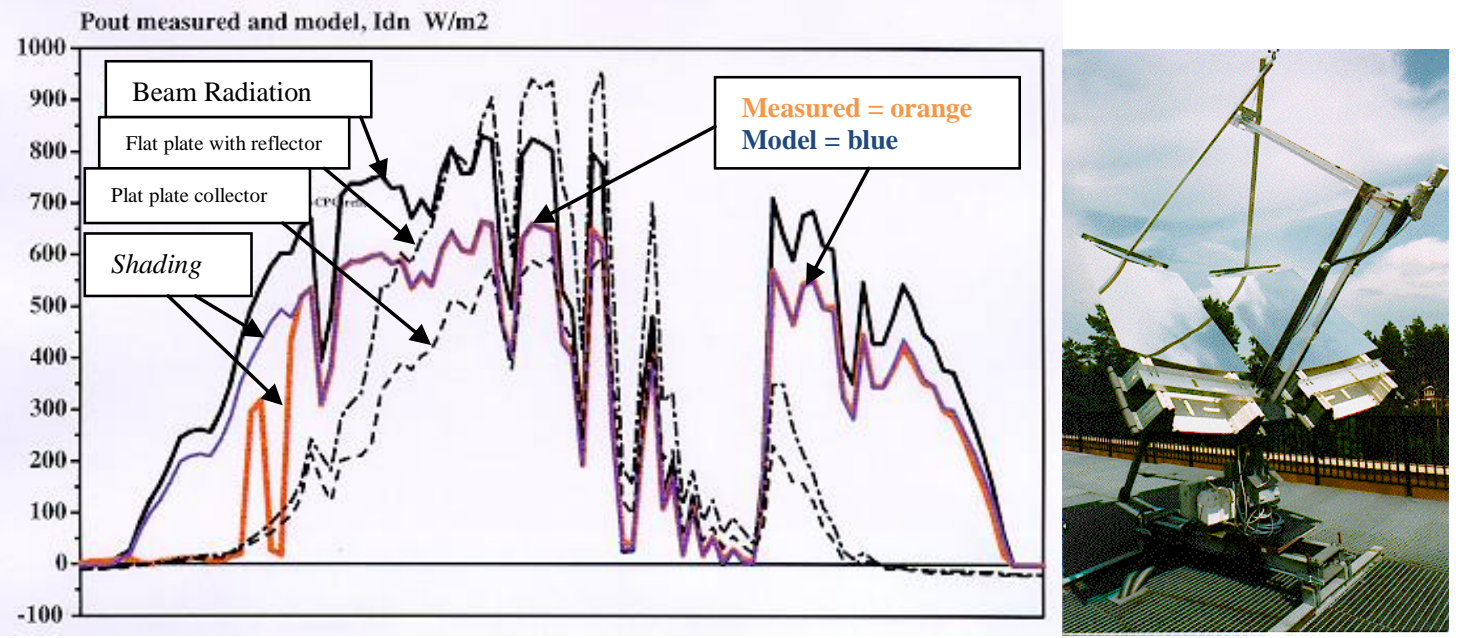

Figure 3. Example of a dynamic test of a concentrating collector of PTC type. Measured (orange) and modelled (blue) power output almost coincide except in the morning with local shading. Reference [7]. 
In the morning there is a short period with collector shading and some tracking errors. Careful check of shading, solar tracking and other operating problems must be part of a test routine. This is a further use of the model called "on line" simulation that can detect operating or measurement problems already when data is collected.

\section{Theory for the energy and mass transfer from water condensation and evaporation}

The collector equation from EN12975 is the starting point and only one additional correction term is proposed for the condensation/evaporation effect for the collector output.

The basic modelling and validation work for the EN 12975 model was done within several IEA groups, as Task III, VI, VII, 14, 26 and 32, during more than 30 years. This model, without condensation effects, has been programmed in the TRNSYS 15 format as type 132 within IEA SH\&C Task 26 Solar Combisystems. Within IEA SH\&C Task 32 and the SOLNET programme the EN12975 model has also been further improved and programmed for TRNSYS 16 [23]. The extended model presented here, equation 6 below, is available as a TRNSYS 16 type as a research tool. Full validation of the condensation effects is still missing though.

Alternative collector modelling of unglazed collectors, including condensation is described in $[13,15]$. In this case the North American FR collector model variant is used, with $\mathrm{T}_{\text {inlet }}$ as collector reference temperature. It is not directly compatible with the EN12975 that use $\mathrm{F}^{\prime}$ and $\mathrm{T}_{\mathrm{m}}$. Important investigations of the wind field around the collector was done here. This is one of the points of special consideration for the modelling unglazed collectors. A single wind speed measured at a meteorological station may not be representative for the collector surface environment without correction.

A very comprehensive characterisation and validation work [18] for unglazed collectors was published already 1985 by J Keller. This was the basis for the author's early work in this field on unglazed collector models and test methods within IEA Task III $[15,16]$. Also work on more general energy balances in outdoor environments for interpretation of infrared thermography [17] was using this theory as a starting point and it was also validated for district heating applications. Stationary testing and modelling of unglazed collectors was presented in [26] with discussion of error bounds, number of terms and long wave radiation measurement accuracy.

During the last years collector modelling- and system simulation work, done at ISFH has been published, including condensation, on the collector surface [14]. The paper indicates that the special metal roofing design can save equivalent to $70-120 \mathrm{kWh} / \mathrm{m} 2$ of electricity in the heat pump electricity use.

Also work at Kassel University has been done in this field to model unglazed collectors. One recent detailed work is presented in [22] for the application of preheating of cold water in open district heating networks. This publication partly questions some of the equation terms and simplifications proposed for unglazed collectors in EN12975. Though, when inserting typical values in the full theory given in the thesis, one can see that the omitted parts are relatively small in terms of power output from the collector. A separate theoretical analyse and experimental investigation of this is needed that can't be included in this paper.

\subsection{Theory for condensation and evaporation on a collector surface}

To extend the collector model to operation at low temperatures below the ambient temperature, existing well validated theory for convection, condensation and evaporation in outdoor conditions has been used [11,12].

This is an adaptation of the classical heat and mass transport theory to the field of unglazed solar collectors. The operation can be divided into two states: 1) Operation below the dew point of the surrounding air, when condensation will occur onto the surface. 2) Operation above the dew point of the air, with a wet collector surface when evaporation will take place. 
In both cases 1 and 2 the moisture flow "g" per $\mathrm{m}^{2}$ of surface per second can be written [12]

$\mathrm{g}=\beta\left(v_{\text {air }}-v_{\text {sat }}\left(\mathrm{t}_{\mathrm{s}}\right)\right)$

$\mathrm{g}=$ moisture flow per $\mathrm{m}^{2}$ collector surface area in $\left[\mathrm{kg} /\left(\mathrm{m}^{2}, \mathrm{~s}\right)\right]$ (positive if condensation on surface "s")

$\beta=\mathrm{h}_{\mathrm{c}} /\left(\rho_{\text {air }} \mathrm{c}_{\mathrm{p} \text { air }}\right)=\mathrm{h}_{\mathrm{m}}$ ( mass transfer coefficient, see details below $)[\mathrm{m} / \mathrm{s}]$

$v=$ humidity density or absolute humidity $\left[\mathrm{kg} / \mathrm{m}^{3}\right]$ (water mass per $\mathrm{m}^{3}$ moist air not water mass per $\mathrm{kg}$ dry air. The English wording humidity density or absolute humidity is used here for $v$ may also be seen as a humidity concentration.)

$\mathrm{t}_{\mathrm{s}}=$ surface temperature $\left[{ }^{\circ} \mathrm{C}\right]$ (Temperature of the collector absorber surface in this case)

$\mathrm{s}=$ surface, sat $=$ saturation, air $=$ ambient air,$c=$ convection, $\mathrm{m}=$ moisture or mass transfer

The "condensation" energy flow per $\mathrm{m}^{2}$ of collector surface is

$\mathrm{q}=\mathrm{g} \mathrm{r}_{\mathrm{w}}=\mathrm{r}_{\mathrm{w}} \beta\left(v_{\text {air }}-v_{\mathrm{s}}\left(\mathrm{t}_{\mathrm{s}}\right)\right)=\mathrm{r}_{\mathrm{w}} \mathrm{h}_{\mathrm{c}} /\left(\rho_{\text {air }} \mathrm{c}_{\mathrm{p} \text { air }}\right)\left(v_{\text {air }}-v_{\text {sat }}\left(\mathrm{t}_{\mathrm{s}}\right)\right)$

$r_{\mathrm{w}}=$ latent evaporation/condensation energy between water and vapour $2260 \mathrm{~kJ} / \mathrm{kg}$.

\subsection{The relation between heat transfer $h_{c}$ and mass transfer $h_{m}$}

It is assumed that the relation between heat and mass transfer in the boundary layer above the collector surface is close to unity (1.0). More exactly this relation between $h_{m}$ and $h_{c}$ can be quantified numerically using the Lewis number $=$ Le.

$\mathrm{Le}=\alpha / \mathrm{D}_{\mathrm{ab}}=\mathrm{Sc} / \mathrm{Pr}$

$\mathrm{Sc}=$ Schmidt number $=\mu_{\text {air }} /\left(\rho_{\text {air }} * \mathrm{D}_{\mathrm{ab}}\right)=\left(\right.$ for air at $\left.20^{\circ} \mathrm{C}\right)=18.1 * 10^{-6} /\left(1.19^{*} 0.25^{*} 10^{-4}\right) \Rightarrow \mathrm{Sc}=0.61$

$\mu_{\text {air }}=$ dynamic viscosity of air $\left(18.1^{*} 10^{-6}\right.$ at $\left.20^{\circ} \mathrm{C}\right)[\mathrm{kg} / \mathrm{ms}]$

$\rho_{\text {air }}=$ density of air $\left(1.19\right.$ at $\left.20^{\circ} \mathrm{C}\right)\left[\mathrm{kg} / \mathrm{m}^{3}\right]$

$\mathrm{D}_{\mathrm{ab}}=$ diffusion coefficient for water vapour in air $\left(0.25^{*} 10^{-4}\right.$ for air at $20^{\circ} \mathrm{C}$ temperature $)$

$\operatorname{Pr}=$ Prandtl number $=\mu_{\text {air }} /\left(\rho_{\text {air }} \alpha_{\text {air }}\right)$

$\alpha=\lambda /\left(\rho \mathrm{c}_{\mathrm{p}}\right)$ the thermal diffusivity for air

$\operatorname{Pr}=\mu_{\text {air }} /\left(\rho_{\text {air }} \lambda_{\text {air }} /\left(\rho_{\text {air }} \mathrm{c}_{\mathrm{p} \text { air }}\right)\right)=\mu_{\text {air }} \mathrm{c}_{\mathrm{p} \text { air }} / \lambda_{\text {air }}=\left(\right.$ for air at $\left.\left.20^{\circ} \mathrm{C}\right)=18.1 * 10^{-6} * 1005 / 0.025 \Rightarrow \operatorname{Pr}=0.72\right)$

$\Rightarrow$

$\mathrm{Le}=\mathrm{Sc} / \mathrm{Pr}=0.61 / 0.72=0.85$

$\mathrm{h}_{\mathrm{c}} / \mathrm{h}_{\mathrm{m}}=\rho_{\text {air }} \mathrm{c}_{\mathrm{p}_{\_} \text {air }}$ Le $\mathrm{e}^{(1-\mathrm{n})} \quad$ adapted from ref [11]

$\Rightarrow$

$\mathrm{h}_{\mathrm{m}}=\beta$ (above in eq. 2$)=\mathrm{h}_{\mathrm{c}} /\left(\rho_{\text {air }} \mathrm{c}_{\mathrm{p} \_ \text {air }} \mathrm{Le}^{(1-\mathrm{n})}\right)$

$\mathrm{h}_{\mathrm{m}}=$ mass transfer coefficient $[\mathrm{m} / \mathrm{s}]$

$\mathrm{n}=1 / 3$ approximately from ref $[11] \Rightarrow \mathrm{Le}^{(1-\mathrm{n})}=0.85^{(1-1 / 3)}=0.90$

A more exact version of equation 2 would then be:

$\mathrm{q}=\mathrm{r}_{\mathrm{w}} \mathrm{h}_{\mathrm{c}} /\left(\rho_{\text {air }} \mathrm{c}_{\mathrm{p}_{-} \text {air }} \operatorname{Le}^{(1-\mathrm{n})}\right)\left(v_{\mathrm{a}}-\mathrm{v}_{\mathrm{sat}}\left(\mathrm{t}_{\mathrm{s}}\right)\right)$

The difference due to a more exact treatment of the relation between heat and mass transfer is only about $10 \%$ in this case for air, at normal outdoor temperatures. This small correction may be neglected or taken into account as a small adjustment of the $c_{7}$ parameter below in equation 6 , at a collector test.

2.3 Calculation of the absolute humidity $v$ from air temperature and relative humidity $v=v_{\text {sat }}\left(\mathrm{t}_{\text {air }}\right) \phi$ 
$v_{\text {sat }}\left(t_{\text {air }}\right)=$ maximum (saturated) absolute humidity of air at a given (dry) temperature $t_{\text {air }}$

$\phi=$ relative humidity of the air, sometimes denoted RH [ - ]

$v_{\text {sat }}\left(\mathrm{t}_{\text {air }}\right)$ at a given temperature $\mathrm{t}$ can be calculated with the following formula from ref [12]

$v_{\text {sat }}\left(\mathrm{t}_{\text {air }}\right)=0.001\left(4.85+0.347 \mathrm{t}+0.00945 \mathrm{t}^{2}+0.000158 \mathrm{t}^{3}+0.00000281 \mathrm{t}^{4}\right) \quad\left[\mathrm{kg} / \mathrm{m}^{3}\right]$

(note the temperature of $\mathrm{t}=\mathrm{t}_{\text {air }}$ is inserted in ${ }^{\circ} \mathrm{C}$ not Kelvin):

2.4 The modelling and calculation of the convection heat transfer coefficient $h_{c}$

The convection coefficient $h_{c}$ has a critical role for the accuracy of this part of the collector model. Empirical correlations have to be used. We propose the form:

$\mathrm{h}_{\mathrm{c}}=\mathrm{A}+\mathrm{B} \quad \mathrm{w}_{\text {coll }} \quad\left(\mathrm{w}_{\text {coll }}=\right.$ wind speed in collector plane $)$

Many other empirical formulas have been proposed, including different values for the A and B constants. The difference at normal wind speeds and collector surface sizes is not so dramatic compared to the uncertainty in the local wind speed $\mathrm{w}_{\text {coll }}$ at the collector surface. One ambitious both theoretical and experimental investigation of this subject is presented in [13]. A recent review paper [17] about convection heat transfer models for solar collectors, proposes a mathematically slightly different formula $h_{c}=5.74 \mathrm{w}_{\text {coll }}^{0.8} \mathrm{~L}^{-0.2}$ for turbulent flow over a solar collector. $\mathrm{L}$ is a characteristic length of the collector. When inserting numbers, typical for a solar collector, the difference to Equation 3 is not very large compared to other uncertainties in the modelling, see figure 4 . Therefore we propose to keep equation 3 as it is, in this case. One can see that except for very low wind speeds the value of $h_{c}$ is very close when using a characteristic length typical for a solar collector. Further experimental investigations in this area are needed, but this is a too wide field for this paper. In real collector test the parameters A and B can be determined for the exact collector geometry if needed.

Wind Convection Heat Transfer at a collector surface. A comparison of models.

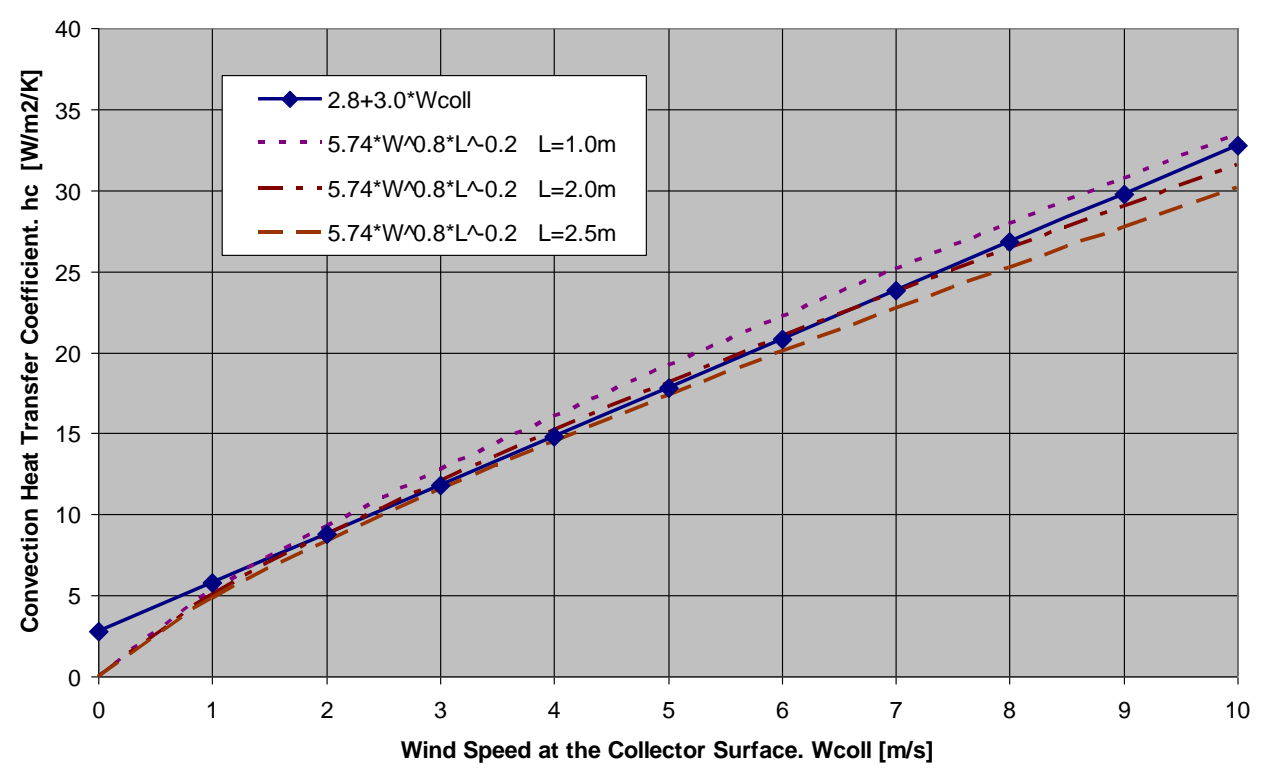

Figure 4. Comparisons of wind convection model proposed in this paper and the review paper [11]. A typical characteristic length $\mathrm{L}$ for a solar collector of 1.5 to $2.5 \mathrm{~m}$ is used.

The main inaccuracy in determining $h_{c}$ is the variation in the wind speed with height above ground and also the large scale additional turbulence caused by nearby objects like trees and buildings. Often only a meteorological value measured at $10 \mathrm{~m}$ above ground is available for simulation. Typically the wind 
speed close to a collector mounted in a built environment is significantly lower than at $10 \mathrm{~m}$ height, but in some cases buildings may enhance the wind speed too.

2.5 The proposed additional condensation/evaporation term for the collector model

The additional total latent energy flow to or from the collector with surface area $\mathrm{A}_{\mathrm{c}}$ is according to equation 2.

$\mathrm{Q}_{\text {latent }}=\mathrm{q} \mathrm{A}_{\mathrm{c}}=\mathrm{A}_{\mathrm{c}} \mathrm{r}_{\mathrm{w}} /\left(\rho_{\text {air }} \mathrm{c}_{\mathrm{p}_{-} \text {air }} \operatorname{Le}^{(1-\mathrm{n})}\right) \mathrm{h}_{\mathrm{c}}\left(v_{\text {air }}-v_{\text {sat }}\left(\mathrm{t}_{\mathrm{s}}\right)\right)$

Using equation 3 and 4 and with the assumption that $t_{s}$ is close to $t_{m}=\left(t_{\text {in }}+t_{\text {out }}\right) 0.5$

$\mathrm{Q}_{\text {latent }}=\mathrm{q} \mathrm{A}_{\mathrm{c}}=\mathrm{A}_{\mathrm{c}} 1.710^{3}\left(\mathrm{~A}+\mathrm{B} \mathrm{w}_{\mathrm{coll}}\right)\left(\mathrm{v}_{\mathrm{a}}-\mathrm{v}_{\text {sat }}\left(\mathrm{t}_{\mathrm{m}}\right)\right)$

The exact values of $A$ and $B$ vary in the literature, but values in the range of $A=2.8$ and $B=3.0$ are given in ref [16] page 174 and in ref [11], for example. These A and B values are also used in figure 2 when comparing models, showing that the parameters $\mathrm{A}$ and $\mathrm{B}$ are in a reasonable range for this application.

In the application of the model for solar collectors on the market these constants may also be determined and corrected for, by testing for each individual collector geometry. The surface roughness, flat surface or round tubes and air gaps between the tubes, will affect the heat transfer rate. One should also keep in mind that this is a correction term in the whole collector equation For example the absorbed solar radiation is often the largest energy flow, also at low operating temperatures, see figure 3. Therefore the optical modelling is often the most important including incidence angle effects.

\section{The extended collector model in the form of EN12975}

Using a similar notation as in ref [4] for the collector equation in EN12975 and adding mass transfer effects according to equation 5 we derive the full dynamic collector model for power output per $\mathrm{m}^{2}$ of collector:

$$
\begin{aligned}
& \mathrm{q}=\mathrm{F}^{\prime}(\tau \alpha)_{\mathrm{en}} \mathrm{K}_{\theta b}\left(\theta_{\mathrm{L}}, \theta_{\mathrm{T}}\right) \mathrm{G}_{\mathrm{b}}+\mathrm{F}^{\prime}(\tau \alpha)_{\mathrm{en}} \mathrm{K}_{\theta \mathrm{d}} \mathrm{G}_{\mathrm{d}}-\mathrm{c}_{6} \mathrm{w}_{\text {coll }} \mathrm{G}_{\mathrm{T}}-\mathrm{c}_{1}\left(\mathrm{t}_{\mathrm{m}}-\mathrm{t}_{\mathrm{a}}\right)-\mathrm{c}_{2}\left(\mathrm{t}_{\mathrm{m}}-\mathrm{t}_{\mathrm{a}}\right)^{2}-\mathrm{c}_{3} \mathrm{w}_{\text {coll }}\left(\mathrm{t}_{\mathrm{m}}-\mathrm{t}_{\mathrm{a}}\right)+ \\
& +\mathrm{c}_{4}\left(\mathrm{E}_{\mathrm{L}}-\sigma \mathrm{T}_{\mathrm{a}}^{4}\right)-\mathrm{c}_{5} \mathrm{dt}_{\mathrm{m}} / \mathrm{d} \tau-\mathrm{c}_{7}\left(2.8-3.0 \mathrm{w}_{\text {coll }}\right)\left(v_{\mathrm{a}}-v_{\text {sat }}\left(\mathrm{t}_{\mathrm{m}}\right)\right)
\end{aligned}
$$

\section{Variables in eq 6:}

$\mathrm{G}_{\mathrm{b}}=$ beam solar radiation in the collector plane [W/m2]

$\mathrm{G}_{\mathrm{b}}=$ diffuse solar radiation in the collector plane $[\mathrm{W} / \mathrm{m} 2]$

$\mathrm{G}_{\mathrm{T}}=$ total (beam + diffuse) solar radiation in the collector plane $[\mathrm{W} / \mathrm{m} 2]$

$\theta_{\mathrm{L}}, \theta_{\mathrm{T}}=$ Incidence angles for beam radiation onto the collector plane in longitudinal and transversal direction from the normal.

$\mathrm{w}_{\text {coll }}=$ wind speed in the collector plane $[\mathrm{m} / \mathrm{s}]$

$\mathrm{t}_{\mathrm{m}}=\left(\mathrm{t}_{\mathrm{in}}+\mathrm{t}_{\mathrm{out}}\right) 0.5$ arithmetic mean fluid temperature between inlet and outlet of the collector $\left[{ }^{\circ} \mathrm{C}\right]$

$\mathrm{E}_{\mathrm{L}}=$ long wave or thermal radiation (incident from sky + ambient) in the collector plane [W/m2]

$\mathrm{T}_{\mathrm{a}}=$ ambient temperature close to the collector (in the shade) $[\mathrm{K}]$ (only radiation calculations)

$\mathrm{t}_{\mathrm{a}}=$ ambient temperature close to the collector (in the shade) $\left[{ }^{\circ} \mathrm{C}\right]$

$v_{\mathrm{a}}=$ absolute humidity of air (derived from measured relative humidity and ambient air temp) $\left[\mathrm{kg} / \mathrm{m}^{3}\right]$

$v_{\text {sat }}\left(t_{\mathrm{m}}\right)=$ calculated saturated absolute humidity, of the ambient air, at temperature $\mathrm{t}_{\mathrm{m}}\left[\mathrm{kg} / \mathrm{m}^{3}\right]$

$\tau=$ time during measurements and simulation. 


\section{Parameters in eq 6:}

$\mathrm{F}^{\prime}(\tau \alpha)_{\mathrm{en}}=$ zero loss efficiency of the collector, at normal incidence

$\mathrm{K}_{\theta b}\left(\theta_{\mathrm{L}}, \theta_{\mathrm{T}}\right)=$ incidence angle modifier for beam solar radiation. $\mathrm{K}_{\theta \mathrm{b}}$ varies with incidence angles $\theta, \theta_{\mathrm{L}}$ and $\theta_{\mathrm{T}}$. Note that for many collector designs like concentrating collectors, vacuum tube's or CPC's, $\mathrm{K}_{\theta b}(\theta)$ is generalised to $\mathrm{K}_{\theta b}\left(\theta_{\mathrm{L}}, \theta_{\mathrm{T}}\right)$ where $\theta_{\mathrm{L}}$, and $\theta_{\mathrm{T}}$ are transversal and longitudinal incidence angles.

$\mathrm{K}_{\theta \mathrm{d}}=$ incidence angle modifier for diffuse solar radiation (assumed to be a fixed value for each collector design). This value can be either determined experimentally in a dynamic test or integrated from beam incidence angle modifier curves [24].

$\mathrm{c}_{1}=$ heat loss coefficient at $\left(\mathrm{t}_{\mathrm{m}}-\mathrm{t}_{\mathrm{a}}\right)=0$ equal to $\mathrm{F}^{\prime} \mathrm{U}_{0}[\mathrm{~W} /(\mathrm{m} 2 \mathrm{~K})]$

$\mathrm{c}_{2}=$ temperature dependence in the heat loss coefficient equal to $\mathrm{F}^{\prime} \mathrm{U}_{1}\left[\mathrm{~W} /\left(\mathrm{m}^{2} \mathrm{~K}^{2}\right)\right]$

$\mathrm{c}_{3}=$ wind speed dependence of the heat losses equal to $\mathrm{F}^{\prime} \mathrm{U}_{\text {wind }}\left[\mathrm{J} /\left(\mathrm{m}^{3} \mathrm{~K}\right)\right]$

$\mathrm{c}_{4}=$ long wave irradiance dependence of the heat losses, equal to $\mathrm{F}^{\prime} \varepsilon[-]$

$\mathrm{c}_{5}=$ effective thermal capacitance, equal to $(\mathrm{mC})_{\mathrm{e}}[\mathrm{J} /(\mathrm{m} 2 \mathrm{~K})]$

$\mathrm{c}_{6}=$ wind dependence of the zero loss efficiency, a collector constant $[\mathrm{s} / \mathrm{m}]$

$\mathrm{c}_{7}=$ humidity factor of collector $[\mathrm{J} / \mathrm{kg}]$. Ideally equal to $\mathrm{r}_{\mathrm{w}} /\left(\rho_{\text {air }} \mathrm{c}_{\mathrm{p}_{-} \text {air }} \mathrm{Le}^{(1-\mathrm{n})}\right)$ for a flat surface and the back side insulated. In reality, the value will depend on the collector design and especially the absorber.

\section{Discussion and Conclusion}

A collector model is available to widen the application of the EN12975 test method to more collector designs and for calculation methods for collectors and systems. The model can also be used for on line simulation in real systems and during collector testing to quickly find errors in operation, sensors and measurement system.

Validation of the extension of the model and test method to collector operation below the dew point of the air, still remains, but classical theory for the latent energy flow is used that is already validated.

Advanced incidence angle modelling is also possible with the extended collector model to asymmetric collectors. Also the option to determine the incidence angle coefficients as a matrix see figure 1 . This matrix can be given as input to the TRNSYS simulation tool and is available for research purposes.

\section{References}

[1] Perers B. Dynamic Method for Collector Array Testing and Evaluation with standard Database and Simulation Programmes. Solar Energy. Vol. 50, no 6, pp. 517-526. (1993).

[2] Perers B. An Improved Dynamic Collector Test Method for determination of Non-Linear Optical and Thermal Characteristics with Multiple Regression. Solar Energy. Vol. 59. No 4-6, pp. 163-178. (1997).

[3] Rönnelid M., Perers B., Karlsson B. On the factorisation of Incidence Angle Modifiers for CPC Collectors. Solar Energy Vol. 99. No. 4-6. pp. 281-286. (1997)

[4] Fischer S., Heidemann W., Müller-Steinhagen H., Perers B., Bergquist P., Hellström B. Collector test method under quasi dynamic conditions according to the European Standard EN 12975-2. Solar Energy. Vol 76 pp 117-123 (2004)

[5] Perers B. A Dynamic Collector Model for Simulation of the operation below the dewpoint in Heat Pump Systems. Eurosun Conference Glasgow (2006). 
[6] Perers B., Karlsson B., Kjellsson E., Hellström G. An Unglased Solar Collector model for the simulation of Ground Source Heat Pump Systems. North Sun 2005.

[7] Helgesson A. Tvåaxligt solföljande PTC-solfångare. Prototypmätningar och utvärdering. Vattenfall Utveckling. UR 97/12. (1997).

[8] Kjellsson E. (2005) Solar Collectors and Ground Source Heat Pump in Combination. North Sun 2005 .

[9] Tepe R., Rönnelid M. and Perers B. 2003 Swedish Solar Systems in Combination with Heat Pumps. Proceeding from ISES Solar World Congress 14-19 June 2003. Göteborg, Sweden.

[10] Kjellsson E. (2004). Solar Heating in Dwellings with Analysis of Combination of Solar Collectors and Ground Source Heat Pump (In Swedish). Report TVBH 3047 Dept of Building Physics Lund University Sweden 2004. www.byfy.lth.se/Publikationer/3000.html

[11] Incropera , De Witt Fundamentals of heat and mass transfer. Page 352-357 + tables of properties. John Whiley \& Sons 1990.

[12] Nevander, Elmarsson. Fukthandboken ISBN 91-7332-716-6 page 236-241, 372-374.

[13] Soltau, H. München 1989. Phd Thesis. Das thermische Verhalten offener Kollektoren. VDI Verlag. ISBN 3-18-143906-1 Page 64-72. (1989).

[14] Eisenmann W. et al. Metal Roofs as Unglased Solar Collectors Coupled with Heat Pump And Ground Storage: System Concepts. Eurosun 2006. ISBN 0904963731.

[15] Pitz-Paal Robert. Kondensation an unabgedeckten sonnenkollektoren. Diplomarbeit Ludvig Maximilians Universität München (1988)

[16] Beckman W, Duffie J. Solar Engineering of Thermal Processes. ISBN 0-471-51056-4 (1991)

[17] Sartori E. Convection Coefficient Equations for forced air over flat surfaces. Solar Energy 80 (2006) 1063-1071.

[18] Keller, J. Characterisation of the Thermal performance of uncovered Solar Collectors. Jülich 1985.

[19] Vindens inflytande på oglasade solfångare respektive solfångare med konvektionshinder. Walletun, H. Eriksson, Leif. Perers, B. Zinko, H. Studsvik Technical Note ED-86/15.

[20] Perers, B. Performance testing of Unglased Collectors. Wind and Longwave Radiation Influence IEA Task III. Studsvik 1987.

[21] Perers, B. Schmeling, Per. Bestämning av Värmeförluster I Fjärrvärmenät med Termografi. Simuleringsmodell för Noggrannare Bildanalys. Stidsvik/ED-89/5 (1989).

[22] Frank, E. Modellierung und Auslegungsoptimierung unabgedeckter Solarkollectoren für die Vorervärmung offener Fernwärmenetze. PHd thesis. Kassel University. (2007) ISBN 978-3-89958$372-4$.

[23] Haller, M. Paavilainen, J. Dalibard, A. Perers, B. TRNSYS Type 832 v 3.07“ Dynamic Collector Model by Bengt Perers. Updated Input Output Reference. ITW Technical University in Graz (2009).

[24] Pettersson, U. Kovacs, P. Perers, B. Improving the compatibility between Steady State and Quasi Dynamic testing for new collector designs. ISES 2009.

[25] Rönnelid, M. Perers,B. Karlsson, B. Construction and Testing of a Large Area CPC Collector and comparison with a Flat Plate Collector. Solar Energy Vol. 57. No. 3. pp. 177-184. (1996).

[26] Morrison, G.L. Gilliaert, D. Unglased Solar Collector Performance Characteristics. J. of Solar Energy Engineering August 1992, Vol.114/195. 